\title{
Thermotoga petrophila sp. nov. and Thermotoga naphthophila sp. nov., two hyperthermophilic bacteria from the Kubiki oil reservoir in Niigata, Japan
}

\author{
1 Marine Biotechnology \\ Institute, Kamaishi \\ Laboratories, 3-75-1 Heita, \\ Kamaishi City, Iwate \\ 026-0001, Japan \\ 2 Marine Biotechnology \\ Institute, Shimizu \\ Laboratories, 1900 Sodeshi, \\ Shimizu City, Shizuoka \\ 424-0037, Japan \\ 3 Taisei Corporation \\ Technology Center, 344-1 \\ Nase-cho Totsuka-ku, \\ Yokohama, Kanagawa \\ 245-0051, Japan
}

\author{
Yoh Takahata, ${ }^{1} \dagger$ Miyuki Nishijima, ${ }^{2}$ Toshihiro Hoaki ${ }^{3}$ \\ and Tadashi Maruyama ${ }^{1}$
}

\begin{abstract}
Author for correspondence: Yoh Takahata. Tel: +81458147226 . Fax: +81458147257. e-mail: yoh.takahata@sakura.taisei.co.jp
\end{abstract}

\begin{abstract}
Two hyperthermophilic bacteria, strains RKU-1' and RKU-10', which grew optimally at $80^{\circ} \mathrm{C}$, were isolated from the production fluid of the Kubiki oil reservoir in Niigata, Japan. They were strictly anaerobic, rod-shaped fermentative heterotrophs. Based on the presence of an outer sheath-like structure (toga) and $16 \mathrm{~S}$ rDNA sequences, they were shown to belong to the genus Thermotoga. Cells of strain RKU-1 ${ }^{\top}$ were $2-7 \mu \mathrm{m}$ by $0.7-1.0 \mu \mathrm{m}$, with flagella. They grew at $47-88^{\circ} \mathrm{C}$ on yeast extract, peptone, glucose, fructose, ribose, arabinose, sucrose, lactose, maltose, starch and cellulose as sole carbon sources. Cells of strain RKU-10 ${ }^{\top}$ were $2-7 \mu \mathrm{m}$ by 0.8-1.2 $\mu \mathrm{m}$, with flagella. They grew at 48-86 ${ }^{\circ} \mathrm{C}$ on yeast extract, peptone, glucose, galactose, fructose, mannitol, ribose, arabinose, sucrose, lactose, maltose and starch as sole carbon sources. While strains RKU-1 ${ }^{\top}$ and $R K U-10^{\top}$ reduced elemental sulfur to hydrogen sulfide, their final cell yields and specific growth rates decreased in the presence of elemental sulfur. Thiosulfate also inhibited growth of strain RKU-1 ${ }^{\top}$ but not strain RKU-10 ${ }^{\top}$. The $\mathbf{G}+C^{2}$ contents of the DNA from strains RKU-1 ${ }^{\top}$ and RKU-10' were 46.8 and $46.1 \mathrm{~mol} \%$. Phenotypic characteristics and 165 rDNA sequences of the isolates were similar to those of Thermotoga maritima and Thermotoga neapolitana, both being hyperthermophilic bacteria isolated from hydrothermal fields. However, the isolates differed from these species in their minimum growth temperatures, utilization of some sugars, sensitivity to rifampicin and the effects of elemental sulfur and thiosulfate on growth. The low levels (less than $31 \%$ ) of DNA reassociation between any two of these hyperthermophilic Thermotoga strains indicated that the isolates were novel species. Analysis of the gyrB gene sequences supported the view that the isolates were genotypically different from these reference species. The isolates were named Thermotoga petrophila sp. nov., with type strain RKU-1' ( = DSM $13995^{\top}=$ JCM $\left.10881^{\top}\right)$, and Thermotoga naphthophila sp. nov., with type strain RKU-10' ( = DSM 13996' $=$ JCM 10882' ${ }^{\top}$ ).
\end{abstract}

Keywords: Thermotoga petrophila, Thermotoga naphthophila, hyperthermophilic bacteria, oil reservoir

\section{INTRODUCTION}

A large number of hyperthermophiles with optimum growth temperatures higher than $80^{\circ} \mathrm{C}$ have been isolated from various hot environments (Stetter, 1996). While most of them are members of the domain

†Present address: Taisei Corporation Technology Center, 344-1 Nase-cho Totsuka-ku, Yokohama, Kanagawa 245-0051, Japan.

Abbreviation: ASW, artificial sea water.

The GenBank/EMBL/DDBJ accession numbers for the $16 \mathrm{~S}$ rDNA sequences of Thermotoga petrophila RKU-1 ${ }^{\top}$, Thermotoga naphthophila RKU-10 ${ }^{\top}$, Thermotoga neapolitana DSM 4359 ${ }^{\top}$ and Thermotoga thermarum DSM 5069 ${ }^{\top}$ are AB027016, AB027017, AB039768 and AB039769. The accession numbers for the gyrB gene sequences of $T$. petrophila RKU-1 ${ }^{\top}$, T. naphthophila RKU-10 ${ }^{\top}$, Thermotoga maritima DSM $3109^{\top}$ and $T$. neapolitana DSM 4359 ${ }^{\top}$ are AB039770-AB039773. 
Archaea, some hyperthermophiles belong to the genera Aquifex and Thermotoga in the domain Bacteria (Blöchl et al., 1995). According to 16S rRNA gene sequencing, they represent the deepest phylogenetic branches within the domain Bacteria (Winker \& Woese, 1991). The members of the genus Thermotoga, in the order Thermotogales, include Thermotoga maritima (Huber et al., 1986), Thermotoga neapolitana (Belkin et al., 1986; Jannasch et al., 1988), Thermotoga thermarum (Windberger et al., 1989), Thermotoga elfii (Ravot et al., 1995a), Thermotoga subterranea (Jeanthon et al., 1995) and Thermotoga hypogea (Fardeau et al., 1997). T. maritima and T. neapolitana grow optimally at $80{ }^{\circ} \mathrm{C}$ and are hyperthermophilic species. In the last decade, hyperthermophilic archaea (Beeder et al., 1994; Grassia et al., 1996; L'Haridon et al., 1995; Orphan et al., 2000; Stetter et al., 1993; Takahata et al., 2000) and thermophilic bacteria with an optimal temperature below $80^{\circ} \mathrm{C}$ (Beeder et al., 1995; Cayol et al., 1995; Greene et al., 1997; Magot et al., 1997; Nilsen et al., 1996; Rees et al., 1995), including T. elfii, T. subterranea and T. hypogea, have been isolated from the production fluids of oil reservoirs. Thermotoga-like bacteria with togas, growing at $65-85^{\circ} \mathrm{C}$, have also been reported from oil reservoirs in Alaska and California (Orphan et al., 2000; Stetter et al., 1993). We describe two novel hyperthermophilic Thermotoga species, Thermotoga petrophila sp. nov. and Thermotoga naphthophila $\mathrm{sp}$. nov., isolated from the Kubiki oil reservoir.

\section{METHODS}

Reference micro-organisms. T. maritima DSM $3109^{\mathrm{T}}, T$. neapolitana DSM 4359 ${ }^{\mathrm{T}}$ and $T$. thermarum DSM 5069 ${ }^{\mathrm{T}}$ were obtained from the DSMZ (Deutsche Sammlung von Mikroorganismen und Zellkulturen), Braunschweig, Germany.

Collection of the sample. The production fluid was taken from the no. 3 storage tank of the Kubiki oil reservoir in Niigata, Japan. The geological structure and physical properties of the Kubiki oil reservoir have been described previously (Takahata et al., 2000). The production fluid was collected in sterile glass bottles, which were then sealed with sterile silicon stoppers and plastic screw caps. They were chilled in a cooler box with ice and transported to the laboratory.

Isolation and cultivation. Anaerobic, heterotrophic hyperthermophiles were grown on YE medium (Takahata et al., 2000) containing $0.2 \%(\mathrm{w} / \mathrm{v})$ yeast extract in artificial sea water (ASW; Jannasch et al., 1995). One litre of ASW contained $20 \mathrm{~g} \mathrm{NaCl}, 3 \mathrm{~g} \mathrm{MgCl} .6 \mathrm{H}_{2} \mathrm{O}, 6 \mathrm{~g} \mathrm{MgSO} \mathrm{Mg}_{4} .7 \mathrm{H}_{2} \mathrm{O}$, $1 \mathrm{~g}\left(\mathrm{NH}_{4}\right)_{2} \mathrm{SO}_{4}, 0.3 \mathrm{~g} \mathrm{CaCl}_{2} .2 \mathrm{H}_{2} \mathrm{O}, 0.2 \mathrm{~g} \mathrm{KH}_{2} \mathrm{PO}_{4}, 0.5 \mathrm{~g} \mathrm{KCl}$, $0.05 \mathrm{~g} \mathrm{NaBr}, 0.025 \mathrm{~g} \mathrm{H}_{3} \mathrm{BO}_{3}, 0.02 \mathrm{~g} \mathrm{SrCl}_{2} .6 \mathrm{H}_{2} \mathrm{O}, 0.01 \mathrm{~g}$ ferric ammonium citrate, $2.25 \mathrm{~g}$ bis-tris propane, $10 \mathrm{ml}$ of a trace mineral solution (Wolin et al., 1963), $10 \mathrm{ml}$ of a vitamin solution (Bazylinski et al., 1989) and $0.6 \mathrm{mg}$ resazurin as a redox indicator. The $\mathrm{pH}$ was adjusted to $7 \cdot 0$ with $6 \mathrm{M} \mathrm{HCl}$ after supplementing the medium with $0.2 \%$ yeast extract at room temperature. Aliquots $(9 \mathrm{ml})$ of the liquid medium were dispensed into $30 \mathrm{ml}$ Hungate tubes (Sanshin Kogyo) and autoclaved at $121^{\circ} \mathrm{C}$ for $20 \mathrm{~min}$. The tubes were flushed with oxygen-free nitrogen through a heated, $\mathrm{H}_{2}$-reduced, copper furnace (Sanshin Kogyo). The tubes were then sealed tightly with sterile butyl-rubber stoppers. Sodium sulfide, which had been sterilized by filtration (disk capsule of $0 \cdot 2 \mu \mathrm{m}$ pore size; Fuji), was added to a final concentration of approximately $400 \mu \mathrm{M}$. After autoclaving, flushing with nitrogen and adding sodium sulfide, the final $\mathrm{pH}$ in the medium was between 6.9 and $7 \cdot 1$ at room temperature. One millilitre of the formation water in the production fluid was inoculated into $9 \mathrm{ml}$ of YE medium in a Hungate tube and incubated at $85^{\circ} \mathrm{C}$ for $1-7 \mathrm{~d}$. Hyperthermophiles were purified by the Gelrite plating method as described previously (Takahata et al., 2000).

Electron microscopy. Cell morphology and flagellation were observed with a transmission electron microscope $(\mathrm{H}-7000$; Hitachi) as described previously (Takahata et al., 2000). The cells were fixed with $2.5 \%$ glutaraldehyde and post-fixed with $1 \%$ osmium tetroxide. Ultrathin sections of the cells embedded in Epon 812 resin were cut with a Reichelt-Nissei Ultracut-N ultramicrotome and doubly stained with uranyl acetate and lead citrate (Reynolds, 1963). After fixation with $2.5 \%$ glutaraldehyde, whole mounted cells were negatively stained with $4 \%$ (w/v) uranyl acetate (Kurr et al., 1991).

Determination of cell numbers. Cell growth was monitored by the acridine orange direct-counting method (Hobbie et al., 1977) under an epifluorescence microscope (model BX60 ; Olympus).

Growth characteristics. The effect of temperature on microbial growth was examined in YE medium with a mineral oil bath (model OH-16; Taitec). The effects of $\mathrm{pH}$ and $\mathrm{NaCl}$ on growth were examined in a YE-based medium incubated at $80^{\circ} \mathrm{C}$. The $\mathrm{pH}$ dependency of growth was determined with various buffer systems, as described previously (Hoaki et al., 1994). The $\mathrm{pH}$ of the medium was checked and readjusted at room temperature after autoclaving, flushing with nitrogen and adding sodium sulfide. The effects of various gaseous phases on microbial growth were examined by using ASW for autotrophic growth or YE medium for heterotrophic growth. The gaseous phase in a Hungate tube was filled with $\mathrm{CO}_{2}, \mathrm{H}_{2}$, air or a mixture of $\mathrm{H}_{2}$ and $\mathrm{CO}_{2}$ (4: 1). To determine the nutritional requirements of the isolates, their growth was examined in $10 \mathrm{ml}$ ASW medium (pH 7.0) without shaking at $80^{\circ} \mathrm{C}$ with one of the following carbon sources at a final concentration of $0 \cdot 1 \%(\mathrm{w} / \mathrm{v})$ : yeast extract, peptone, casein, albumin, Casamino acids, a mixture of 20 amino acids, glucose, galactose, fructose, mannitol, ribose, arabinose, xylose, sucrose, lactose, maltose, starch, acetate, lactate, formate, propionate, maleic and citric acids, methanol and ethanol. Growth was also examined in the presence of $1 \%(\mathrm{v} / \mathrm{v})$ cellulose, chitin, kerosene, light oil, A-heavy oil (Nippon Mitsubishi Oil) or crude oil in $30 \mathrm{ml}$ ASW medium ( $\mathrm{pH} 7 \cdot 0$ ) with shaking. Crude oil was obtained from the Kubiki oil reservoir. To confirm growth on any of the substrates, the isolate was subcultured twice in the same medium.

Metabolic products. Metabolic products $\left[\mathrm{H}_{2}, \mathrm{CO}_{2}\right.$ and lowmolecular-mass $\left(\mathrm{C}_{2}-\mathrm{C}_{5}\right)$ organic acids] were analysed by HPLC and GC as described previously (Takahata et al., 2000). D-Glucose was analysed with a glucose analysis kit (no. 716251; Boehringer Mannheim).

Effect of electron acceptors. The effects of sulfate $(20 \mathrm{mM})$, thiosulfate $(20 \mathrm{mM})$ and elemental sulfur $(2 \%)$ as electron acceptors on growth of the isolates were examined in YEbased medium in which $\mathrm{MgSO}_{4} \cdot 7 \mathrm{H}_{2} \mathrm{O}$ and $\left(\mathrm{NH}_{4}\right)_{2} \mathrm{SO}_{4}$ had been replaced with $\mathrm{MgCl}_{2} \cdot 6 \mathrm{H}_{2} \mathrm{O}$ and $\mathrm{NH}_{4} \mathrm{Cl}$. Hydrogen sulfide production was analysed with a gas analysis kit (Gastec). 


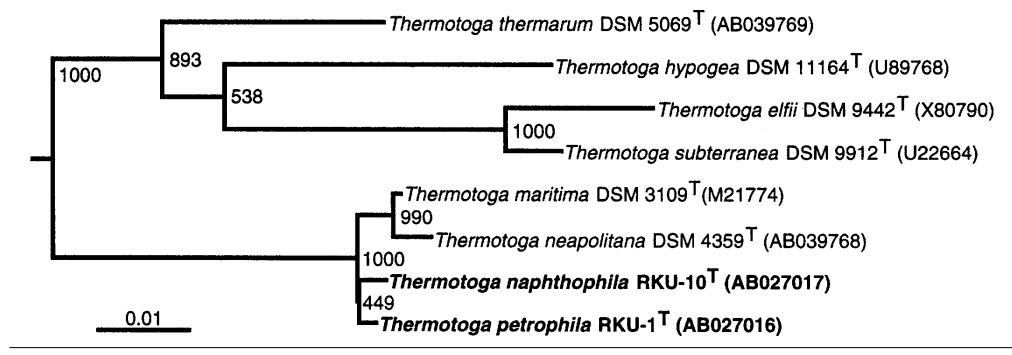

Fig. 1. Neighbour-joining phylogenetic tree of the members of Thermotoga, including strains RKU- $1^{\top}$ and RKU-10 ${ }^{\top}$, based on $16 \mathrm{~S}$ rDNA sequences. The $16 \mathrm{~S}$ rDNA sequences of T. maritima, T. hypogea, T. subterranea, T. elfii were obtained from the GenBank/EMBL/DDBJ database. The corresponding sequences of $T$. neapolitana and $T$. thermarum were determined in this study. Outgroup: Thermosipho melanesiensis DSM 12029 ${ }^{\top}$ (Z70248). Bar, 1 base substitution per 100 nucleotide positions.

Sensitivity to antibiotics. The sensitivity of the isolates to rifampicin, streptomycin, vancomycin and chloramphenicol was examined at a concentration of $100 \mu \mathrm{g} \mathrm{m} l^{-1}$ in YE medium at $70{ }^{\circ} \mathrm{C}$ for $7 \mathrm{~d}$.

Isolation of DNA. Genomic DNA was extracted from each isolate by using a procedure described elsewhere (Ausubel et al., 1987) with a slight modification. RNA was digested with $20 \mu \mathrm{g}$ DNase-free RNase $\mathrm{ml}^{-1}$ at $37^{\circ} \mathrm{C}$ for $1 \mathrm{~h}$ after extracting with chloroform/isoamyl alcohol.

DNA base composition. The nucleotide composition was determined by HPLC with a Develosil ODS-HG-5 column $(4.6 \times 250 \mathrm{~mm})$ and a UV detector (model UV 8010; Tosoh) at $270 \mathrm{~nm}$ after digesting the DNA with nuclease P1 (Zillig et al., 1980).

16S rDNA sequence analysis. PCR was used to amplify $16 \mathrm{~S}$ rDNA from the genomic DNA of each isolate using primers B0R (Escherichia coli positions 8-27; 5'-AGAGTTTGATCCTGGCTCAG-3') and B9 (1491-1512; 5'-TACGGCTACCTTGTTACGACTT-3') (Takahata et al., 2000). A total of 35 cycles of amplification was performed with template DNA denaturation at $94{ }^{\circ} \mathrm{C}$ for $1 \mathrm{~min}$, primer annealing at $58^{\circ} \mathrm{C}$ for $1 \mathrm{~min}$ and primer extension at $72^{\circ} \mathrm{C}$ for $2 \mathrm{~min}$. After purifying the PCR products with a QIAEX II gel extraction kit (QIAGEN), the 16S rDNA sequence was determined with an ABI Big Dye Terminator cycle sequencing ready reaction kit (Perkin-Elmer) and an ABI 377 DNA sequencer (Perkin-Elmer). The sequences determined were then aligned with reference $16 \mathrm{~S}$ rDNA sequences obtained from the GenBank/EMBL/DDBJ database. A multiple alignment was obtained by using CLUSTAL W version 1.7 (Higgins et al., 1996; Thompson et al., 1994). A phylogenetic tree was constructed by using the same software using the neighbour-joining method (Saitou \& Nei, 1987). The reliability of cluster formation was analysed by bootstrap resampling 1000 times.

gyrB sequence analysis. PCR was used to amplify partial gyrB sequences from the genomic DNA of the isolates by using the pair of primers TTG-UF ( $T$. maritima positions 841-860; 5'-CAGGAAACAGCTATGACCGAYGGNGGNACNCAYGTNAC-3') and TTG-UR (T. maritima positions 1219-1238; 5'-TGTAAAACGACGGCCAGTCARTCNGCNARYTTNCCNGG-3') (Guipaud et al., 1996). A total of 35 cycles of amplification was performed with denaturation at $94{ }^{\circ} \mathrm{C}$ for $1 \mathrm{~min}$, primer annealing at $52{ }^{\circ} \mathrm{C}$ for $1 \mathrm{~min}$ and primer extension at $72^{\circ} \mathrm{C}$ for $2 \mathrm{~min}$. The methods for purification of the PCR products and determination of the $g y r B$ sequences were the same as those used for $16 \mathrm{~S}$ rDNA. The amplified fragments were sequenced with primers M13Rev (5'-CAGGAAACAGC-
TATGACC-3') and -21M13 (5'-TGTAAAACGACGGCCAGT-3') (Messing et al., 1977). The similarity of each determined sequence was calculated by GENETYX-MAC 8.0 (Software Development).

DNA-DNA hybridization. DNA-DNA hybridization between the novel isolates, $T$. maritima and $T$. neapolitana was determined by the fluorometric hybridization method in microdilution wells (Ezaki et al., 1989). The DNA probes were labelled with photobiotin and hybridization was performed at $43{ }^{\circ} \mathrm{C}$ for $20 \mathrm{~h}$. The optimal temperature for renaturation $\left(T_{\mathrm{or}}\right)$ was calculated from the following equation: $T_{\text {or }}\left({ }^{\circ} \mathrm{C}\right)=0 \cdot 41 \times \mathrm{G}+\mathrm{C}$ content $(\mathrm{mol} \%)+24 \cdot 3$.

\section{RESULTS AND DISCUSSION}

\section{Isolation and 16S rDNA sequence analysis}

Two hyperthermophilic bacterial strains, RKU- $1^{\mathrm{T}}$ and RKU-10 $0^{\mathrm{T}}$, were isolated from a deep subterranean oil reservoir in Niigata, Japan. They were obligately anaerobic heterotrophic rods with a 'toga', a sheathlike structure with ballooning at both ends, which is characteristic of members of the order Thermotogales. Phylogenetic analysis using 16S rDNA sequences showed that the novel isolates belong to the genus Thermotoga and they were most closely related to the hyperthermophilic species $T$. maritima and $T$. neapolitana (Fig. 1), which were isolated from marine hydrothermal fields (Belkin et al., 1986; Huber et al., 1986). Three previously described Thermotoga species, $T$. subterranea, T. elfii and T. hypogea, have also been isolated from oil reservoirs (Fardeau et al., 1997; Jeanthon et al., 1995; Ravot et al., 1995a). However, the phylogenetic tree of 16S rDNA sequences revealed that these three species formed a clade distinct from the hyperthermophilic Thermotoga species (Fig. 1).

\section{Morphological and phenotypic properties}

Cells of strain RKU-1 ${ }^{\mathrm{T}}$ were $2-7 \mu \mathrm{m}$ long and $0 \cdot 7-1 \cdot 0 \mu \mathrm{m}$ wide. Cells of strain RKU- $10^{\mathrm{T}}$ were $2-7 \mu \mathrm{m}$ long and $0.8-1 \cdot 2 \mu \mathrm{m}$ wide. In the stationary growth phase, the cell shape became spherical, with a diameter of 1-2 $\mu \mathrm{m}$. While T. maritima has a single subpolar flagellum (Huber et al., 1986) and T. neapolitana lacks flagella (Belkin et al., 1986), strains RKU-1 ${ }^{\mathrm{T}}$ and RKU-10 ${ }^{\mathrm{T}}$ possessed several subpolar and lateral flagella (Fig. 2a, b). Similar flagellation has been 

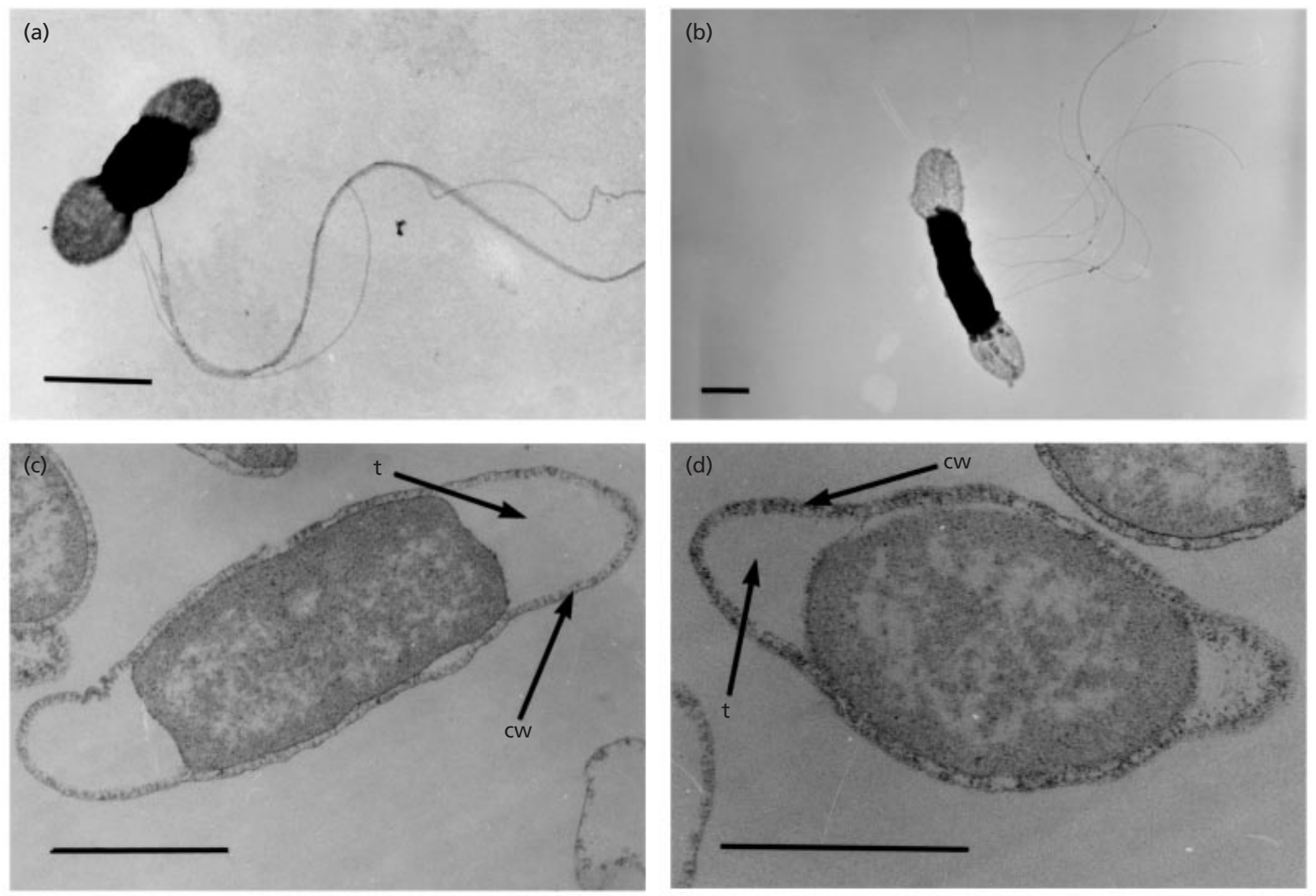

Fig. 2. (a)-(b) Electron micrographs of negatively stained cells of strains $R K U-1^{\top}$ (a) and $R K U-10^{\top}$ (b). (c)-(d) Electron micrographs of doubly stained ultrathin sections of cells of strains RKU $-1^{\top}$ (c) and RKU $-10^{\top}$ (d). Arrows indicate the toga (t) and cell wall (cw). Bars, $1 \mu \mathrm{m}$.

shown for cells of $T$. elfii and T. hypogea. Electron microscopy of thin sections of the isolates showed a cell wall approximately $50 \mathrm{~nm}$ thick (Fig. 2c, d).

The temperature ranges for growth were $47-88^{\circ} \mathrm{C}$ with an optimum at $80^{\circ} \mathrm{C}$ for strain $\mathrm{RKU}-1^{\mathrm{T}}$ and $48-86{ }^{\circ} \mathrm{C}$ with an optimum at $80^{\circ} \mathrm{C}$ for RKU-10 (Fig. 3a). No growth was apparent at 46 or $89^{\circ} \mathrm{C}$ $\left(\mathrm{RKU}-1^{\mathrm{T}}\right)$ and at 47 or $87^{\circ} \mathrm{C}\left(\mathrm{RKU}-10^{\mathrm{T}}\right)$. At $80^{\circ} \mathrm{C}$, the respective doubling times of strains RKU-1 ${ }^{\mathrm{T}}$ and RKU- $10^{\mathrm{T}}$ were 54 and $59 \mathrm{~min}$. While T. maritima and $T$. neapolitana also grow optimally at $80^{\circ} \mathrm{C}$, they are not able to grow at temperatures below $55^{\circ} \mathrm{C}$ (Belkin et al., 1986; Huber et al., 1986). The optimum temperatures of other Thermotoga species isolated from oil reservoirs have been reported to be $66-70{ }^{\circ} \mathrm{C}$ (Fardeau et al., 1997; Jeanthon et al., 1995; Ravot et al., 1995a). The $\mathrm{pH}$ ranges for growth were 5.2-9.0 $\left(\mathrm{RKU}-\mathrm{1}^{\mathrm{T}}\right)$ and 5.4-9.0 (RKU-10 $\left.{ }^{\mathrm{T}}\right)$, with the optimum at 7.0 for both (Fig. 3b). No growth was apparent at $\mathrm{pH} 5 \cdot 0$ or $9 \cdot 5\left(\mathrm{RKU}-1^{\mathrm{T}}\right)$ and at $\mathrm{pH} 5 \cdot 2$ or $9 \cdot 5(\mathrm{RKU}-$ $\left.10^{\mathrm{T}}\right)$. These ranges are about the same as those of $T$. maritima and T. neapolitana (Belkin et al., 1986; Huber et al., 1986). The $\mathrm{NaCl}$ concentration ranges for growth were $0 \cdot 1-5 \cdot 5 \% \quad\left(\mathrm{RKU}-1^{\mathrm{T}}\right)$ and $0 \cdot 1-6 \cdot 0 \%$ (RKU-10 $10^{\mathrm{T}}$, with the optimum at $1.0 \%$ for both
(Fig. 3c). No growth was apparent at concentrations of 0 or $6 \%\left(\mathrm{RKU}-1^{\mathrm{T}}\right)$ and at 0 or $6.5 \%\left(\mathrm{RKU}-10^{\mathrm{T}}\right)$. In contrast, thermophilic Thermotoga species from oil reservoirs required lower levels of salinity $(\mathrm{NaCl}$ concentration range for growth 0-2.8\%) (Fardeau et al., 1997; Jeanthon et al., 1995; Ravot et al., 1995a).

The isolates did not grow aerobically or autotrophically with a mixture of $\mathrm{H}_{2}$ and $\mathrm{CO}_{2}$ (4:1). Carbon dioxide did not affect heterotrophic growth of the isolates in YE medium. They could grow in YE medium with a hydrogen atmosphere, but their final cell yields were only about $10 \%$ of those with nitrogen. They grew on yeast extract, peptone and various sugars. Growth of the novel isolates, T. maritima and $T$. neapolitana on various sugars is shown in Table 1. All of the strains could grow on all the sugars tested except mannitol or xylose as the sole carbon and energy source, although the final cell densities after incubation for $48 \mathrm{~h}$ at $80{ }^{\circ} \mathrm{C}$ were different (Table 1). Strain RKU-1 ${ }^{\mathrm{T}}$ grew weakly on cellulose, but stain RKU $-10^{\mathrm{T}}$ did not. Neither strain RKU-1 ${ }^{\mathrm{T}}$ nor RKU$10^{\mathrm{T}}$ grew on proteins (casein or albumin), amino acids (Casamino acids or a mixture of 20 amino acids), organic acids (acetate, lactate, formate, propionate, maleic or citric acid), alcohols (methanol or ethanol), 

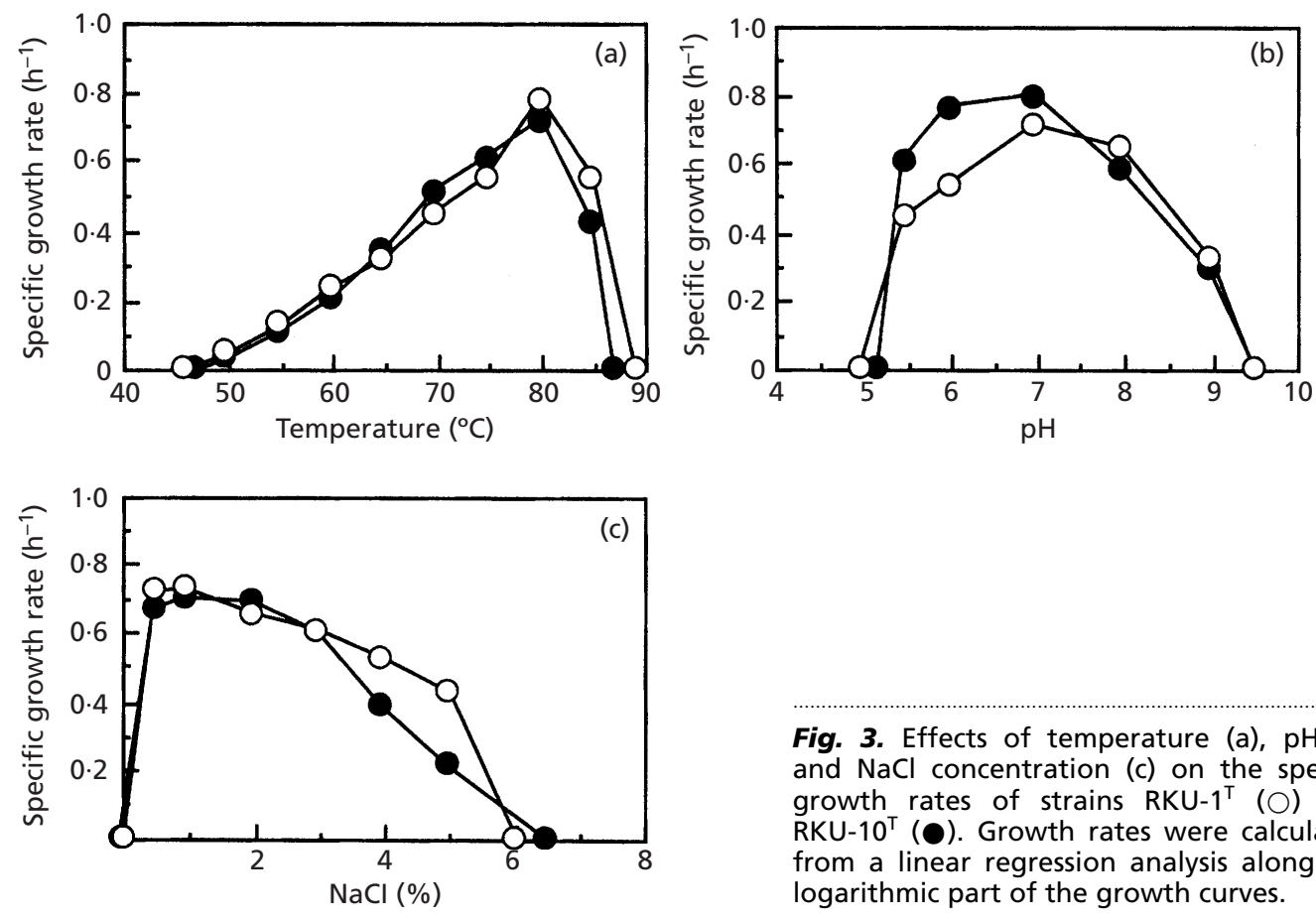

Fig. 3. Effects of temperature (a), $\mathrm{pH}$ (b) and $\mathrm{NaCl}$ concentration (c) on the specific growth rates of strains $\mathrm{RKU}-1^{\top}(O)$ and RKU-10 10 . Growth rates were calculated from a linear regression analysis along the logarithmic part of the growth curves.

Table 1. Growth of hyperthermophilic Thermotoga strains on various sugars

The initial cell density was adjusted to approximately $10^{4}$ cells $\mathrm{ml}^{-1}$. Growth was evaluated from the final cell density after incubation for $48 \mathrm{~h}$ at $80^{\circ} \mathrm{C}$, and is scored as:,$+++>10^{8}$ cells ml $^{-1}$; ,$++ 10^{7}-10^{8}$ cells $\mathrm{ml}^{-1} ;+, 10^{6}-10^{7}$ cells $\mathrm{ml}^{-1} ;-$, no growth. All four taxa were scored as + for growth on arabinose.

\begin{tabular}{|lcccc|}
\hline Sugar & RKU-1 $^{\mathbf{T}}$ & RKU-10 $^{\mathbf{T}}$ & T. maritima & T. neapolitana \\
\hline Glucose & + & ++ & +++ & ++ \\
Galactose & ++ & ++ & +++ & +++ \\
Fructose & ++ & +++ & ++ & ++ \\
Mannitol & - & ++ & - & +++ \\
Ribose & +++ & ++ & +++ & ++ \\
Xylose & - & ++ & +++ & ++ \\
Sucrose & ++ & ++ & ++ & ++ \\
Lactose & +++ & ++ & +++ & ++ \\
Maltose & +++ & ++ & +++ & +++ \\
Starch & +++ & & & + \\
\hline
\end{tabular}

Table 2. Fermentation of glucose by strains RKU-1 ${ }^{\top}$ and $R K U-10^{\top}$

Glucose consumed was calculated by subtracting the glucose concentration after cultivation from that before cultivation. Metabolites produced were measured after incubation for $100 \mathrm{~h}$ in ASW containing $0 \cdot 1 \%$ glucose at $80{ }^{\circ} \mathrm{C}$.

\begin{tabular}{|c|c|c|c|c|c|c|c|c|}
\hline \multirow[t]{2}{*}{ Strain } & \multicolumn{2}{|c|}{ Cell density (cells ml ${ }^{-1}$ ) } & \multirow[t]{2}{*}{ Glucose consumed (mM) } & \multicolumn{4}{|c|}{ Production of $(\mathrm{mM})$ : } & \multirow[t]{2}{*}{ Total carbon recovery $(\%)$} \\
\hline & Initial & Final & & Lactate & Acetate & $\mathrm{CO}_{2}$ & $\mathbf{H}_{2}$ & \\
\hline RKU-1 ${ }^{\mathrm{T}}$ & $5 \cdot 2 \times 10^{4}$ & $7 \cdot 3 \times 10^{6}$ & $0 \cdot 27$ & $0 \cdot 07$ & $0 \cdot 48$ & $0 \cdot 11$ & $1 \cdot 01$ & $79 \cdot 0$ \\
\hline RKU-10 $0^{\mathrm{T}}$ & $6.3 \times 10^{4}$ & $1.2 \times 10^{7}$ & $1 \cdot 36$ & $1 \cdot 05$ & $1 \cdot 72$ & 0.56 & $5 \cdot 39$ & $87 \cdot 6$ \\
\hline
\end{tabular}



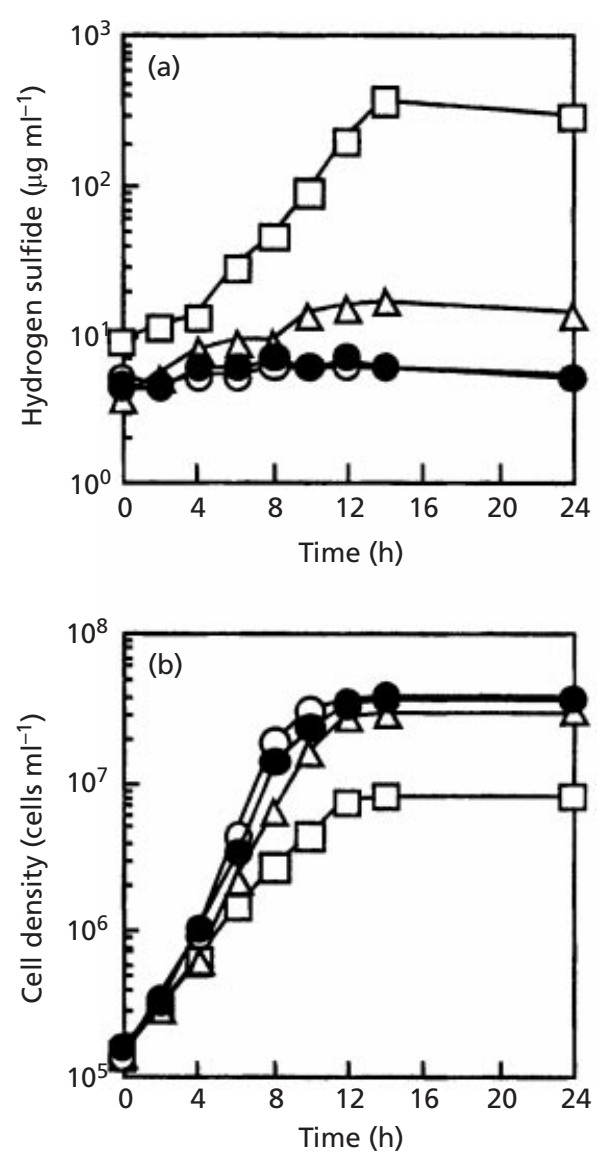

Fig. 4. Effects of electron acceptors on the growth of strain RKU $-10^{\top}$. Production of hydrogen sulfide (a) and growth (b) are shown with no additions (O) or with the addition of $20 \mathrm{mM}$ sulfate $(\bigcirc), 20 \mathrm{mM}$ thiosulfate $(\triangle)$ or $2 \%$ elemental sulfur $(\square)$.

chitin or hydrocarbons (kerosene, light oil, A-heavy oil or crude oil) as the sole carbon and energy source.

Lactate, acetate, $\mathrm{CO}_{2}$ and $\mathrm{H}_{2}$ were produced by strains RKU-1 ${ }^{\mathrm{T}}$ and RKU-10 ${ }^{\mathrm{T}}$ during growth on glucose. The concentration of glucose consumed and those of the final fermentation products after cultivation at $80{ }^{\circ} \mathrm{C}$ for $100 \mathrm{~h}$ are shown in Table 2 . The ratio of acetate/ lactate in strain RKU-10 $0^{\mathrm{T}}(2 \cdot 8)$ was higher than those in strain RKU- $1^{\mathrm{T}}(1 \cdot 64)$ and T. maritima $(0 \cdot 40$; Huber et al., 1986).

Sulfur utilization was reported to be one of the discriminatory characteristics between hyperthermophilic Thermotoga species from hydrothermal fields and thermophilic Thermotoga species from oil reservoirs (Fardeau et al., 1997). While elemental sulfur has been reported to enhance the final cell yields and specific growth rates of $T$. maritima and $T$. neapolitana by removing growth-inhibitory $\mathrm{H}_{2}$ (Ravot et al., 1995b), it inhibited the growth of T. elfii and $T$. subterranea (Jeanthon et al., 1995; Ravot et al., 1995a). Strains RKU- $1^{\mathrm{T}}$ (data not shown) and RKU-10 ${ }^{\mathrm{T}}$ (Fig. 4a) did not reduce sulfate to hydrogen sulfide but did reduce sulfur and thiosulfate. The final yields of $\mathrm{H}_{2} \mathrm{~S}$ production from elemental sulfur by these two strains were almost the same (about $400 \mu \mathrm{g} \mathrm{ml}{ }^{-1}$; Fig. 4a). While RKU-1 ${ }^{\mathrm{T}}$ (data not shown) and RKU$10^{\mathrm{T}}$ (Fig. 4b) reduced elemental sulfur to $\mathrm{H}_{2} \mathrm{~S}$, their final cell yields and specific growth rates were reduced. Growth of six Thermotoga reference strains was stimulated by thiosulfate reduction (Ravot et al., 1996). Strain RKU-1 ${ }^{\mathrm{T}}$ also reduced thiosulfate to $\mathrm{H}_{2} \mathrm{~S}$ (120 $\mu \mathrm{g} \mathrm{ml}^{-1}$; data not shown), but its final cell yield and specific growth rate were reduced. The final yield of $\mathrm{H}_{2} \mathrm{~S}$ from thiosulfate by strain RKU- $10^{\mathrm{T}}$ was much less than that of strain RKU-1 ${ }^{\mathrm{T}}$ (approx. $10 \mu \mathrm{g} \mathrm{ml}^{-1}$; Fig. 4a). The final cell yield and specific growth rate were not affected significantly by the presence of thiosulfate (Fig. 4b). These results indicate that the utilization of sulfur or thiosulfate by these isolates from Japanese oil reservoirs was quite different from that of Thermotoga reference species.

Strains RKU- $1^{\mathrm{T}}$ and RKU- $10^{\mathrm{T}}$ did not grow in YE medium containing $100 \mu \mathrm{g}$ rifampicin, streptomycin, vancomycin or chloramphenicol $\mathrm{ml}^{-1}$ at $70{ }^{\circ} \mathrm{C}$ within $7 \mathrm{~d}$. In contrast, T. maritima and T. neapolitana were not sensitive to rifampicin at the same concentration (Belkin et al., 1986; Huber et al., 1986).

These results indicated that the morphological and phenotypic properties of strains RKU- ${ }^{\mathrm{T}}$ and RKU$10^{\mathrm{T}}$, such as type of flagellum, minimum growth temperature, sugar utilization, effects of sulfur and thiosulfate on growth and rifampicin sensitivity, were clearly different from those of $T$. maritima and $T$. neapolitana. They also differed from other Thermotoga species isolated from oil reservoirs in their optimum growth temperature, range of $\mathrm{NaCl}$ concentrations for growth and effects of sulfur and thiosulfate on growth. However, the morphological and phenotypic properties of these two isolates were quite similar, except in mannitol and cellulose utilization and thiosulfate reduction.

\section{Genotypic analysis}

The DNA $\mathrm{G}+\mathrm{C}$ contents of strains $\mathrm{RKU}-\mathrm{1}^{\mathrm{T}}$ and RKU- $10^{\mathrm{T}}$ were $46 \cdot 6$ and $46 \cdot 1 \mathrm{~mol} \%$. These $\mathrm{G}+\mathrm{C}$ contents are similar to that of T. maritima (46 mol \%). DNA reassociation values between any two of the hyperthermophilic Thermotoga strains were 11.0 $30.8 \%$ (Table 3 ). According to the criteria of Wayne et al. (1987), these results indicate that each of the new isolates should be classified as a distinct species.

The 16S rDNA sequence evolves so slowly that it is not suitable for distinguishing closely related species. The $\operatorname{gyr} B$ gene, encoding the subunit B protein of DNA gyrase (topoisomerase type II), has been proposed to be more suitable to distinguish closely related species (Yamamoto et al., 1999). Amplified gyrB gene fragments from strains RKU-1 $1^{\mathrm{T}}$ and RKU $-10^{\mathrm{T}}, T$. maritima and $T$. neapolitana were sequenced directly and their partial gyrB sequences $(358 \mathrm{bp})$ were determined. The similarity $(77 \cdot 8-94 \cdot 7 \%$; Table 3$)$ of $\operatorname{gyr} B$ sequences between any two of the four hyper- 
Table 3. Nucleotide sequence similarity of gyrB and DNA-DNA hybridization between hyperthermophilic Thermotoga strains

Values above the diagonal are percentage sequence similarities of $\operatorname{gyr} B$ gene sequences. Values below the diagonal are mean percentages of DNA reassociation, and the minimum and maximum values are given in parentheses $(n=3)$.

\begin{tabular}{|lcccc|}
\hline Strain & $\mathbf{1}$ & $\mathbf{2}$ & $\mathbf{3}$ & $\mathbf{4}$ \\
\hline 1. RKU-1 $^{\mathrm{T}}$ & - & $86 \cdot 0$ & $94 \cdot 7$ & $77 \cdot 8$ \\
2. RKU-10 & $15 \cdot 0(10 \cdot 3-17 \cdot 4)$ & - & $85 \cdot 7$ & $77 \cdot 9$ \\
3. Thermotoga maritima DSM $3109^{\mathrm{T}}$ & $16 \cdot 9(10 \cdot 0-28 \cdot 1)$ & $25 \cdot 7(21 \cdot 1-28 \cdot 3)$ & - & $78 \cdot 4$ \\
4. Thermotoga neapolitana DSM $4359^{\mathrm{T}}$ & $11 \cdot 0(8 \cdot 3-15 \cdot 9)$ & $11 \cdot 1(5 \cdot 8-14 \cdot 9)$ & $30 \cdot 8(25 \cdot 2-35 \cdot 3)$ & - \\
\hline
\end{tabular}

thermophilic Thermotoga strains was much less than that in their $16 \mathrm{~S}$ rDNA sequences $(99 \cdot 1-99 \cdot 6 \%)$. These results support the genotypic difference among them.

On the basis of their phenotypic characteristics and phylogenetic relationships, the two isolates from a Japanese oil reservoir are thought to be novel species. They are designated Thermotoga petrophila sp. nov., with the type strain RKU-1 ${ }^{\mathrm{T}}$, and Thermotoga naphthophila sp. nov., with the type strain RKU-10 ${ }^{\mathrm{T}}$.

\section{Description of Thermotoga petrophila sp. nov.}

Thermotoga petrophila (pe.tro'phi.la. Gr. n. petros rock; Gr. adj. philos loving; N.L. fem. adj. petrophila rock-loving).

Cells are rods, $2-7 \mu \mathrm{m}$ long by $0 \cdot 7-1 \mu \mathrm{m}$ wide. Cells possess an outer sheath-like structure (toga) and several subpolar and lateral flagella. Heterotrophic and obligate anaerobe of the domain Bacteria. The temperature for growth is $47-88^{\circ} \mathrm{C}$, with the optimum at $80{ }^{\circ} \mathrm{C}$. The $\mathrm{pH}$ range for growth is $5 \cdot 2-9 \cdot 0$, with the optimum at $7 \cdot 0$. The $\mathrm{NaCl}$ concentration range for growth is $0.1-5.5 \%$, with the optimum at $1.0 \%$. The doubling time at the optimum temperature is $54 \mathrm{~min}$. Requires yeast extract, peptone, glucose, galactose, fructose, ribose, arabinose, sucrose, lactose, maltose, starch or cellulose as the sole carbon and energy source. The end products from glucose fermentation are acetate, lactate, $\mathrm{H}_{2}$ and $\mathrm{CO}_{2}$. While the cells reduce elemental sulfur or thiosulfate to $\mathrm{H}_{2} \mathrm{~S}$, their growth rate and cellular yield decrease in the presence of these electron acceptors. Sensitive to $100 \mu \mathrm{g}$ rifampicin, streptomycin, vancomycin or chloramphenicol $\mathrm{ml}^{-1}$. The DNA G + C content is $46.6 \mathrm{~mol} \%$. Isolated from the formation water of production fluid in the Kubiki oil reservoir.

The type strain is RKU $-1^{\mathrm{T}}\left(=\mathrm{DSM} 13995^{\mathrm{T}}=\mathrm{JCM}\right.$ $10881^{\mathrm{T}}$ ).

\section{Description of Thermotoga naphthophila sp. nov.}

Thermotoga naphthophila (naph.tho'phi.la. Gr. n. naphtha bitumen; Gr. adj. philos loving; N.L. fem. adj. naphthophila bitumen-loving).
Cells are rods, $2-7 \mu \mathrm{m}$ long by $0 \cdot 8-1 \cdot 2 \mu \mathrm{m}$ wide. Cells possess an outer sheath-like structure (toga) and several subpolar and lateral flagella. Heterotrophic and obligate anaerobe of the domain Bacteria. The temperature for growth is $48-86{ }^{\circ} \mathrm{C}$, with the optimum at $80{ }^{\circ} \mathrm{C}$. The $\mathrm{pH}$ range for growth is $5 \cdot 4-9 \cdot 0$, with the optimum at 7.0. The $\mathrm{NaCl}$ concentration range for growth is $0 \cdot 1-6.0 \%$, with the optimum at $1.0 \%$. The doubling time at the optimum temperature is $59 \mathrm{~min}$. Requires yeast extract, peptone, glucose, galactose, fructose, mannitol, ribose, arabinose, sucrose, lactose, maltose or starch as the sole carbon and energy source. The end products from glucose fermentation are acetate, lactate, $\mathrm{H}_{2}$ and $\mathrm{CO}_{2}$. While the cells reduce elemental sulfur to $\mathrm{H}_{2} \mathrm{~S}$, their growth rate and cellular yield decrease in the presence of elemental sulfur. While the species reduces thiosulfate weakly to $\mathrm{H}_{2} \mathrm{~S}$, thiosulfate shows no effect on the growth rate or cellular yield. Sensitive to $100 \mu \mathrm{g}$ rifampicin, streptomycin, vancomycin or chloramphenicol $\mathrm{ml}^{-1}$. The DNA $\mathrm{G}+\mathrm{C}$ content is $46.1 \mathrm{~mol} \%$. Isolated from the formation water of production fluid in the Kubiki oil reservoir.

The type strain is RKU-10 ${ }^{\mathrm{T}}$ (= DSM $13996^{\mathrm{T}}=\mathrm{JCM}$ $\left.10882^{\mathrm{T}}\right)$.

\section{ACKNOWLEDGEMENTS}

We thank Teikoku Oil Co. Ltd for contributing the samples and information about the Kubiki oil reservoir. We are grateful to M. Kurihara, R. Aburaki and N. Okita for their capable technical assistance. We also thank S. Yamamoto, H. Kasai and T. Hamada for their advice in this study. S. Harayama is acknowledged for his critical advice throughout this research. H. G. Trüper is acknowledged for advice about the nomenclature of the new isolates.

\section{REFERENCES}

Ausubel, F. M., Brent, R., Kingston, R. E., Moore, D. D., Seidman, J. G., Smith, J. A. \& Struhl, K. (editors) (1987). Current Protocols in Molecular Biology, unit 2.4. New York: Wiley.

Bazylinski, D. A., Wirsen, C. O. \& Jannasch, H. W. (1989). Microbial utilization of naturally-occurring hydrocarbons at the Guaymas Basin hydrothermal vent site. Appl Environ Microbiol $\mathbf{5 5}, 2832-2836$ 
Beeder, J., Nilsen, R. K., Rosnes, J. T., Torsvik, T. \& Lien, T. (1994). Archaeoglobus fulgidus isolated from hot North Sea oil field waters. Appl Environ Microbiol 60, 1227-1231.

Beeder, J., Torsvik, T. \& Lien, T. (1995). Thermodesulforhabdus norvegicus gen. nov., sp. nov., a novel thermophilic sulfatereducing bacterium from oil field water. Arch Microbiol 164 331-336.

Belkin, C., Wirsen, C. O. \& Jannasch, H. W. (1986). A new sulfurreducing, extremely thermophilic eubacterium from a submarine thermal vent. Appl Environ Microbiol 51, 1180-1185.

Blöchl, E., Burggraf, S., Fiala, G., Lauerer, G., Huber, R., Rachel, R., Segerer, A., Stetter, K. O. \& Völkl, P. (1995). Isolation, taxonomy and phylogeny of hyperthermophilic microorganisms. World $J$ Microbiol Biotechnol 11, 9-16.

Cayol, J.-L., Ollivier, B., Patel, B. K. C., Ravot, G., Magot, M., Ageron, E., Grimont, P. A. D. \& Garcia, J.-L. (1995). Description of Thermoanaerobacter brockii subsp. lactiethylicus subsp. nov., isolated from a deep subsurface French oil well, a proposal to reclassify Thermoanaerobacter finnii as Thermoanaerobacter brockii subsp. finnii comb. nov., and an emended description of Thermoanaerobacter brockii. Int J Syst Bacteriol 45, 783-789.

Ezaki, T., Hashimoto, Y. \& Yabuuchi, E. (1989). Fluorometric deoxyribonucleic acid-deoxyribonucleic acid hybridization in microdilution wells as an alternative to membrane filter hybridization in which radioisotopes are used to determine genetic relatedness among bacterial strains. Int $J$ Syst Bacteriol 39, 224-229.

Fardeau, M.-L., Ollivier, B., Patel, B. K. C., Magot, M., Thomas, P., Rimbault, A., Rocchiccioli, F. \& Garcia, J.-L. (1997). Thermotoga hypogea sp. nov., a xylanolytic, thermophilic bacterium from an oil-producing well. Int J Syst Bacteriol 47, 1013-1019.

Grassia, G. S., McLean, K. M., Glénat, P., Bauld, J. \& Sheehy, A. J. (1996). A systematic survey for thermophilic fermentative bacteria and archaea in high temperature petroleum reservoirs. FEMS Microbiol Ecol 21, 47-58.

Greene, A. C., Patel, B. K. C. \& Sheehy, A. J. (1997). Deferribacter thermophilus gen. nov., sp. nov., a novel thermophilic manganese- and iron-reducing bacterium isolated from a petroleum reservoir. Int J Syst Bacteriol 47, 505-509.

Guipaud, O., Labedan, B. \& Forterre, P. (1996). A gyrB-like gene from the hyperthermophilic bacterium Thermotoga maritima. Gene 174, 121-128.

Higgins, D. G., Thompson, J. D. \& Gibson, T. J. (1996). Using CLUSTAL for multiple sequence alignments. Methods Enzymol 266, 383-402.

Hoaki, T., Nishijima, M., Kato, M., Adachi, K., Mizobuchi, S., Hanzawa, N. \& Maruyama, T. (1994). Growth requirements of hyperthermophilic sulfur-dependent heterotrophic archaea isolated from a shallow submarine geothermal system with reference to their essential amino acids. Appl Environ Microbiol 60, 2898-2904.

Hobbie, J. E., Daley, R. J. \& Jasper, S. (1977). Use of Nuclepore filters for counting bacteria by fluorescence microscopy. Appl Environ Microbiol 33, 1225-1228.

Huber, R., Langworthy, T. A., König, H., Thomm, M., Woese, C. R., Sleytr, U. B. \& Stetter, K. O. (1986). Thermotoga maritima sp. nov. represents a new genus of unique extremely thermophilic eubacteria growing up to $90^{\circ} \mathrm{C}$. Arch Microbiol 144, 324-333.

Jannasch, H. W., Huber, R., Belkin, S. \& Stetter, K. O. (1988). Thermotoga neapolitana sp. nov. of the extremely thermophilic, eubacterial genus Thermotoga. Arch Microbiol 150, 103-104.
Jannasch, H. W., Wirsen, C. O. \& Hoaki, T. (1995). Isolation and cultivation of heterotrophic hyperthermophiles from deep-sea hydrothermal vents. In Archaea : a Laboratory Manual, protocol 1, pp. 9-13. Edited by F. T. Robb, A. R. Place, K. R. Sowers, H. J. Schreier, S. DasSarma \& E. M. Fleischmann. Cold Spring Harbor, NY: Cold Spring Harbor Laboratory.

Jeanthon, C., Reysenbach, A.-L., L'Haridon, S., Gambacorta, A., Pace, N. R., Glénat, P. \& Prieur, D. (1995). Thermotoga subterranea sp. nov., a new thermophilic bacterium isolated from a continental oil reservoir. Arch Microbiol 164, 91-97.

Kurr, M., Huber, R., König, H., Jannasch, H. W., Fricke, H., Trincone, A., Kristjansson, J. K. \& Stetter, K. O. (1991). Methanopyrus kandleri, gen. and sp. nov. represents a novel group of hyperthermophilic methanogens, growing at $110^{\circ} \mathrm{C}$. Arch Microbiol 156, 239-247.

L'Haridon, S., Reysenbach, A.-L., Glénat, P., Prieur, D. \& Jeanthon, C. (1995). Hot subterranean biosphere in a continental oil reservoir. Nature 377, 223-224.

Magot, M., Ravot, G., Campaignolle, X., Ollivier, B., Patel, B. K. C., Fardeau, M.-L., Thomas, P., Crolet, J.-L. \& Garcia, J.-L. (1997). Dethiosulfovibrio peptidovorans gen. nov., sp. nov., a new anaerobic, slightly halophilic, thiosulfate-reducing bacterium from corroding offshore oil wells. Int $J$ Syst Bacteriol 47 , 818-824.

Messing, J., Gronenborn, B., Müller-Hill, B. \& Hopfschneider, P. H. (1977). Filamentous coliphage $\mathrm{M} 13$ as a cloning vehicle: insertion of a HindII fragment of the lac regulatory region in M13 replicative form in vitro. Proc Natl Acad Sci USA 74, 3642-3646.

Nilsen, R. K., Torsvik, T. \& Lien, T. (1996). Desulfotomaculum thermocisternum $\mathrm{sp}$. nov., a sulfate reducer isolated from a hot North Sea oil reservoir. Int J Syst Bacteriol 46, 397-402.

Orphan, V. J., Taylor, L. T., Hafenbradl, D. \& Delong, E. F. (2000). Culture-dependent and culture-independent characterization of microbial assemblages associated with high-temperature petroleum reservoirs. Appl Environ Microbiol 66, 700-711.

Ravot, G., Magot, M., Fardeau, M.-L., Patel, B. K. C., Prensier, G., Egan, A., Garcia, J.-L. \& Ollivier, B. (1995a). Thermotoga elfii sp. nov., a novel thermophilic bacterium from an African oilproducing well. Int J Syst Bacteriol 45, 308-314.

Ravot, G., Ollivier, B., Magot, M., Patel, B. K. C., Crolet, J.-L., Fardeau, M.-L. \& Garcia, J.-L. (1995b). Thiosulfate reduction, an important physiological feature shared by members of the order Thermotogales. Appl Environ Microbiol 61, 2053-2055.

Ravot, G., Ollivier, B., Fardeau, M.-L., Patel, B. K. C., Andrews, K. T., Magot, M. \& Garcia, J.-L. (1996). L-Alanine production from glucose fermentation by hyperthermophilic members of the domains Bacteria and Archaea: a remnant of an ancestral metabolism? Appl Environ Microbiol 62, 2657-2659.

Rees, G. N., Grassia, G. S., Sheehy, A. J., Dwivedi, P. P. \& Patel, B. K. C. (1995). Desulfacinum infernum gen. nov., sp. nov., a thermophilic sulfate-reducing bacterium from a petroleum reservoir. Int J Syst Bacteriol 45, 85-89.

Reynolds, E. S. (1963). The use of lead citrate at high $\mathrm{pH}$ as an electron-opaque stain in electron microscopy. Cell Biol 17, 208-211.

Saitou, M. \& Nei, M. (1987). The neighbor-joining method: a new method for reconstructing phylogenetic trees. Mol Biol Evol 4, 406-425.

Stetter, K. O. (1996). Hyperthermophilic prokaryotes. FEMS Microbiol Rev 18, 149-158.

Stetter, K. O., Huber, R., Blochl, E., Kurr, M., Eden, R. D., Fielder, 
M., Cash, H. \& Vance, I. (1993). Hyperthermophilic archaea are thriving in deep North Sea and Alaskan reservoirs. Nature $\mathbf{3 6 5}$, 743-745.

Takahata, Y., Nishijima, M., Hoaki, T. \& Maruyama, T. (2000). Distribution and physiological characteristics of hyperthermophiles in the Kubiki oil reservoir in Niigata, Japan. Appl Environ Microbiol 66, 73-79.

Thompson, J. D., Higgins, D. G. \& Gibson, T. J. (1994). CLUSTAL $\mathrm{W}$ : improving the sensitivity of progressive multiple sequence alignment through sequence weighting, position-specific gap penalties and weight matrix choice. Nucleic Acids Res 22, 4673-4680.

Wayne, L. G., Brenner, D. J., Colwell, R. R. \& 9 other authors (1987). International Committee on Systematic Bacteriology. Report of the ad hoc committee on reconciliation of approaches to bacterial systematics. Int J Syst Bacteriol 37, 463-464.

Windberger, E., Huber, R., Trincone, A., Fricke, H. \& Stetter, K. O.
(1989). Thermotoga thermarum sp. nov. and Thermotoga neapolitana occurring in African continental solfataric springs. Arch Microbiol 151, 506-512.

Winker, S. \& Woese, C. R. (1991). A definition of the domains Archaea, Bacteria and Eucarya in terms of small subunit ribosomal RNA characteristics. Syst Appl Microbiol 13, 161-165.

Wolin, E. A., Wolin, M. J. \& Wolfe, R. S. (1963). Formation of methane by bacterial extracts. J Biol Chem 238, 2882-2886.

Yamamoto, S., Bouvet, P. J. M. \& Harayama, S. (1999). Phylogenetic structures of the genus Acinetobacter based on gyr $B$ sequences: comparison with the grouping by DNA-DNA hybridization. Int J Syst Bacteriol 49, 87-95.

Zillig, W., Stetter, K. O., Wunderl, S., Schulz, W., Priess, H. \& Scholz, J. (1980). The Sulforobus-' Caldariella' group: taxonomy on the basis of the structure of DNA-dependent RNA polymerases. Arch Microbiol 125, 259-269. 